\title{
ARTYKUtY
}

Klio. Czasopismo poświęcone dziejom Polski i powszechnym

PL ISSN 1643-8191, t. 46 (3)/2018, s. 89-107

(c) (1) $\Theta$

KATARZYNA BRZEZINA-SCHEUERER

\section{Między wiarą a wiedzą. Zainteresowanie księcia Hieronima Floriana Radziwiłła naturą i medycyną}

\author{
Between Faith and Knowledge. \\ Prince Hieronim Florian Radziuiłł's Interest \\ in Nature and Medicine
}

Streszczenie: książę Hieronim Florian Radziwiłł (1715-1760) należał niewątpliwie do malowniczych osobowości północno-wschodnich terenów dawnej Rzeczypospolitej. W prezentowanym artykule zajęto się szczegółowiej kolekcjonowanymi przez Hieronima Floriana Radziwiłła naturaliami, wchodzącymi - jak się wydaje - przynajmniej częściowo w skład jego gabinetu osobliwości, a także starano się przedstawić zainteresowania księcia tematami z zakresu medycyny.

* Uniwersytet Jagielloński, Instytut Historii Sztuki, ul. Grodzka 53, 31-001 Kraków, katarzyna.brzezina@uj.edu.pl; ORCID: 0000-0002-4106-1075. 
Abstract: without a doubt, prince Hieronim Florian Radziwiłł (1715-1760) belonged to a group of the most picturesque personalities of the north-eastern territories of the former Polish-Lithuanian Commonwealth. In the present article, an attempt has been made to present in more detail the collection of natural objects gathered by Hieronim Florian Radziwiłł which constituted, at least in part, a fragment of his wider collection of cabinet of curiosities; an attempt has also been made to present the prince's interest in topics associated with medicine.

Słowa kluczowe: Hieronim Florian Radziwiłł, kolekcje (zbiór naturaliów), gabinet osobliwości, medycyna, zainteresowanie naturą

Keywords: Hieronim Florian Radziwiłł, collections (collection of natural objects), cabinet of curiosities, medicine, interest in nature

$\mathrm{K}$ siążę Hieronim Florian Radziwiłł (1715-1760), syn kanclerza wielkiego litewskiego Karola Stanisława i wojewodzianki trockiej Anny z Sanguszków Radziwiłłowej, od 1739 roku podczaszy litewski, zaś od 1750 roku chorąży wielki litewski, należał niewątpliwie do malowniczych osobowości północno-wschodnich terenów Rzeczypospolitej czasów nowożytnych ${ }^{1}$. Dawniej jego postać była z reguły przedstawiana w ciemnych barwach, do czego wydatnie przyczyniły się osiemnastowieczne pamiętniki oraz dziewiętnastowieczne teksty literatów, publicystów i gawędziarzy² Naszkicowany tam portret księcia ukazywał zazwyczaj człowieka egocen-

${ }^{1}$ Podstawowe dane biograficzne zob. H. Dymnicka-Wołoszyńska, Radziwitt Hieronim Florian, Polski stownik biograficzny, t. 30, Wrocław 1987, s. 185-188.

${ }^{2}$ Zob. np. Pamiętnik Marcina Matuszewicza, kasztelana brzeskiego-litewskiego (1714-1765), t. 3, wyd. A. Pawiński, Warszawa 1876, s. 85, a także E. Kotłubaj, Galeria nieświeska portretów Radziwittowskich, Wilno 1857, s. 423-432; J. Bartoszewicz, Zamek bialski, Lwów 1881, s. 98-101; J. I. Kraszewski, Na bialskim zamku. Powieść historyczna z czasów Augusta III, (wyd. 1: 1882), Warszawa 1966. Zob. też późniejsze publikacje: K. Bartoszewicz, Radziwittowie. Początek i dzieje rodu, typy i charaktery. Rycerze, zdrajcy, pobożni, filantropi, dziwacy. Obrazy z życia domowego. Kobiety Radziwittowskie. Upadek Nieświeża i jego odrodzenie, Warszawa-Kraków 1927, s. 103-118; A. Sajkowski, Od Sierotki do Rybeńki. W kręgu Radziwittowskiego mecenatu, Poznań 1965, s. 175-188; B. Królikowski, Wśród Sarmatów. Radziwittowie i pamiętnikarze, Lublin 2000, s. 200-219. 
trycznego, apodyktycznego, pysznego, okrutnego, o niezbyt lotnym umyśle, a z czasem zdziwaczałego i zabobonnego. Wśród jego zainteresowań najczęściej wymieniano myślistwo, której to pasji poświęcał sporo czasu3 W XX i XXI wieku badacze starają się spojrzeć na Hieronima Floriana bardziej obiektywnie, choć jego negatywne cechy - w szczególności okrucieństwo - są nadal silnie podkreślane. Zauważono więc w pierwszym rzędzie miłość księcia do teatru i muzyki ${ }^{4}$, a także jego starania o gospodarczy rozwój należących do niego włości, w tym przede wszystkim jego głównej siedziby w Białej (d. Białej Radziwiłłowskiej lub Książęcej, obecnie Białej

3 Warto tu przypomnieć, że książę był kawalerem Orderu św. Huberta oraz autorem interesującego Kompendium, w którym ciekawy w sztuce myśliwskiej wiele profitować może, ile że jest z praktyki samej, a nie z ksiag koncypowane w roku pańskim 1740 od dnia 29 augusta. Tekst ten został wydany w: Hieronima Floriana Radziwitta diariusze i pisma różne, oprac. i wstęp M. Brzezina, Warszawa 1998, s. 201-211. W literaturze przedmiotu często można natknąć się na wzmianki o myśliwskich zamiłowaniach księcia, zob. np. S. Krogulski, Kult św. Huberta w Polsce, „Łowiec. Organ Małopolskiego Towarzystwa Łowieckiego" 1926, 16 czerwca (wyd. jubileuszowe), s. 4; T. Bernatowicz, Ogrody do zabaw myśliwskich. Królewskie zwierzyńce czasów saskich wokót Warszawy, w: Królewskie ogrody w Polsce, (Materiały sesji naukowej, Warszawa 10-11 maja 2001), red. M. Szafrańska, Warszawa 2001, s. 276.

${ }^{4}$ A. Sajkowski, Hieronim Florian Radziwitt i jego teatr - Biata Podlaska i Stuck, „Pamiętnik Teatralny” 1962, t. 11, z. 3-4, s. 443-460; idem, Od Sierotki do Rybeńki. W kręgu Radziwittowskiego mecenatu, Poznań 1965, s. 188-207; I. Bieńkowska, Relacja patron - artysta: Hieronim Florian Radziwitt (1715-1760) i jego muzycy, „Polski Rocznik Muzykologiczny” 2004, t. 3, s. 33-47; eadem, Zespoty muzyczno-teatralne Biatej i Stucka $w$ korespondencji Hieronima Floriana Radziwitta (1715-1760), „Barok. Historia-Literatura-Sztuka” 2005, t. 12/1 (23), s. 61-75; eadem, Stuck, teatr i muzyka w rezydencji Hieronima Floriana Radziwitta, w: Dwór polski, zjawisko historyczne i kulturowe (Materiały VIII Seminarium Oddziału Kieleckiego Stowarzyszenia Historyków Sztuki, Kielce 13-15 października 2005), Kielce 2006, s. 281-295; eadem, Wzmianki o balecie egzotycznym na dworze Hieronima Floriana Radziwitta (1715-1760), „Barok. Historia-LiteraturaSztuka” 2008, t. 15/1 (29), s. 189-203; eadem, Mecenas i tyran. Życie muzyczne w rezydencjach Hieronima Floriana Radziwitta (1715-1760) w świetle kontraktów stużbowych zawieranych z artystami, w: Środowiska kulturotwórcze i kontakty kulturalne Wielkiego Księstwa Litewskiego od XV do XIX wieku, red. U. Augustyniak, Warszawa 2009, s. 55-67; eadem, Muzyka na dworze księcia Hieronima Floriana Radziwitta, Warszawa 2013. 
Podlaskiej) $)^{5}$. Jerzy Kowalczyk obszernie omówił stosunek księcia do sztuki i artystów, wspominając ponadto o jego zainteresowaniach naukowo-technicznych ${ }^{6}$. Tadeusz Bernatowicz zaprezentował z kolei nieznane dotąd projekty szeroko zakrojonej przebudowy rezydencji w Białej, planowanej przez Hieronima Floriana ${ }^{7}$. Pisząca te słowa starała się ukazać zamiłowania kolekcjonerskie księcia, prezentując jego gabinet osobliwości ${ }^{8}$. O tych zbiorach wspomniał też m.in. Janusz Goliński', a niedawno Hanna Jurkowska przypomniała „zwierzęce kurioza” w kolekcji bialskiego Radziwiłła ${ }^{10}$. Janusz Goliński, a także Paweł Gad przeanalizowali poglądy magnata na temat edukacji, podkreślając - mimo surowości niektórych zaleceń - ich logiczność ${ }^{11}$. Sylwetkę Hieronima Floriana Radziwiłła, jego mit oraz twórczość

${ }^{5}$ A. Rachuba, Biata pod rządami Radziwittów w latach 1568-1813, w: Z nieznanej przesztości Biatej i Podlasia, red. T. Wasilewski, Biała Podlaska 1990, s. 52. Na zainteresowanie swymi dobrami wskazują też liczne podróże księcia w celu ich lustracji oraz wyjazdy związane z nabywaniem nowych posiadłości, zob. P. Gad, W interesach i dla rozrywki: podróże Hieronima Floriana Radziwitta, „Pisma Humanistyczne” 2014, t. 12, s. 53-67.

${ }^{6}$ J. Kowalczyk, Hieronima Floriana Radziwitta stosunek do sztuki i artystów, w: Kultura artystyczna Wielkiego Księstwa Litewskiego w epoce baroku, red. J. Kowalczyk, Warszawa 1995, s. 27-42.

7 T. Bernatowicz, Niezrealizowana „królewska” rezydencja w Biatej Podlaskiej, w: Artyści wtoscy w Polsce. XV-XVIII wiek, red. J. Chrościcki et al., Warszawa 2004, s. 499-512. O dziejach rezydencji bialskiej zob. ostatnio: D. Antonowicz, K. Kimic, Rezydencja magnacka Radziwittów w Biatej Podlaskiej - historia, przemiany, stan przetrwania, „Kwartalnik Architektury i Urbanistyki” 2017, t. 62, nr 4, s. 25-53.

${ }^{8}$ K. Brzezina, Gabinet osobliwości Hieronima Floriana Radziwitta w Biatej, „Studia Podlaskie" 1997, t. 7, s. 5-20.

9 J. K. Goliński, „Pamiętając o tym, że raz umrzeć trzeba...”. Hieronima Floriana Radziwitta wizerunek wtasny, w: Między barokiem a oświeceniem. Sarmacki konterfekt, red. S. Achremczyk, Olsztyn 2002 (Rozprawy i Materiały Ośrodka Badań Naukowych im. Wojciecha Kętrzyńskiego w Olsztynie, nr 218), s. 165-166.

${ }^{10}$ H. Jurkowska, ,Bazyliszek prawdziwy, jednorożcowych rogów dwa, zasuszony w catości krokodyl..." Zwierzęce kurioza Hieronima Floriana Radziwitta, w: Ludzie i zwierzęta, red. R. Chymkowski, A. Jaroszuk, Warszawa 2014 („Pongo”, t. 6), s. 227-235.

${ }^{11}$ J. K. Goliński, O wychowanie spadkobierców. Nad, instrukcją dla synów” Hieronima Floriana Radziwitta, w: Między barokiem a oświeceniem. Radości i troski dnia codziennego, red. S. Achremczyk, Olsztyn 2006, s. 344-355; P. Gad, „Ojcowskim sercem i stowem”- instrukcja wychowawcza autorstwa Hieronima Floriana Radziwitta, „Ogrody Nauk i Sztuk” 2016, t. 6, s. 215-226 (http://ogrodynauk.pl/index.php/onis/article/viev/10.155503. 
pisarską przestawiła Maria Brzezina we Wstępie do wydania diariuszy (z lat 1747-1751 oraz diariusza podróży do Wiednia w 1756 roku) i innych pism księcia ${ }^{12}$. O jego legendzie pisał też szerzej Janusz Goliński ${ }^{13}$. Obecnie coraz intensywniej poddaje się analizie osobiste życie Hieronima Floriana Radziwiłła ${ }^{14}$.

Zachowane materiały, a przede wszystkim diariusze magnata, pozwalają - przynajmniej częściowo - poznać jego poglądy i pasje. Na kartach owych rękopisów jawi się on jako człowiek zafrapowany zagadnieniami natury, co przejawia się m.in. w dbałości o lasy, ogrody i - darzone przez niego szczególnym sentymentem - zwierzyńce, po których często oprowadzał swych gości ${ }^{15}$. Powodem do dumy księcia była także pomarańczarnia z egzotycznymi roślinami, z którą nie mogła równać się żadna inna (przynajmniej w okolicy) „ni w grubości drzew, ni w gatunkach owoców i kwiatów [...], a jeszcze barziej w liczbie [roślin]" 16 . Hieronim Florian Radziwiłł chętnie oglądał i podziwiał przyrodę zarówno w swoich włościach, jak i w czasie

onis2016.215.226; dostep: 1.05.2018). Artykuły te oparto na tekście Radziwiłła pt. Edukacja która, gdy mi Bóg wszechmogący pozwoli mieć dziatki, dać myśle, a w zajściu na mnie jakowej nieszczęśliwości skąd i śmierci, naznaczonych ode mnie opiekunów by dziatwie mej dawali, upraszam, na Sad Boski zapozywają, gdy przeciwna temu tu opisaniu dawać będą, opublikowanym przez Marię Brzezinę w: Hieronima Floriana Radziwitta diariusze i pisma różne, s. 185-200.

${ }_{12}$ M. Brzezina, Wstęp, w: Hieronima Floriana Radziwitta diariusze i pisma różne, s. 7-23. W Zamku Królewskim w Warszawie (kolekcja Tomasza Niewodniczańskiego) jest przechowywany jeszcze jeden rok zapisów diariuszowych Radziwiłła (1746).

${ }^{13}$ J. K. Goliński, „Pamiętając o tym, że raz umrzeć trzeba...”, s. 162-170.

${ }^{14}$ Zob. np. A. Skrzypietz, Hieronim Florian Radziwitt w zalotach, w: Codzienność i niecodzienność oświeconych, t. 2: W rezydencji, w podróży i na scenie publicznej, red. B. Mazurkowa, M. Marcinkowska, Sz. P. Dąbrowski, Katowice 2013, s. 101-114; "Gdybym Cię, moje Serce, za męża nie miata, żyć bym nie mogta”. Listy Magdaleny z Czapskich do Hieronima Floriana Radziwitta z lat 1744-1759, wstęp i oprac. I. Maciejewska, K. Zawilska, Olsztyn 2016.

${ }^{15}$ Zob. Rzeczy, którymi najgodniejszego mogę zabawić gościa będacego w domu mym, do jakiego zaś czasu, pomiarkuje czytajac taskawy czytelnik, w: Hieronima Floriana Radziwitta diariusze i pisma różne, s. 171-175.

${ }^{16} \mathrm{Ibidem}, \mathrm{s.}$ 171. Była to zapewne wolno stojąca budowla, z trzema dużymi murowanymi, dobrze doświetlonymi pomieszczeniami. 
podróży ${ }^{17}$. To zainteresowanie naturą szczególnie wyraźnie zaznaczyło się w tworzonej przez niego kolekcji. Ujawniło się ono także przez zajmowanie się problemami zdrowotnymi. Właśnie te dwa ostatnie zagadnienia wyjątkowo dobrze ilustrują fascynacje księcia naturą i medycyną.

Wypada zatem przyjrzeć się najpierw kolekcji naturaliów księcia Hieronima Floriana Radziwiłła, współtworzącej jego gabinet osobliwości ${ }^{18}$. Jak wiadomo, w tego typu zbiorach wyraźnie zaznaczała się chęć zgromadzenia obiektów, które pozwalałyby na zdobycie całej dostępnej wówczas wiedzy o świecie. Łączyło się to z ideą mikro- i makrokosmosu, według której świat ziemski był niejako odbiciem wyższego porządku kosmicznego. Gabinet osobliwości można w tym kontekście widzieć jako alegorię wszechświata ${ }^{19}$. Takie myślenie odpowiadało też komplementarnemu spojrzeniu na naukę, dzięki której próbowano zgłębić mechanizmy

${ }^{17}$ Zob. np. Diariusz podróży mej pod tytutem niejakiego dworzanina lub barona Mirskiego a [die] 10. februari zaczęty roku 1756, w: Hieronima Floriana Radziwitta diariusze i pisma różne, s. 160-170. Przypomnijmy tu niektóre jego uwagi: „Byłem itidem w Szenbrun [tak: zamiast "Schönbrunn «] widzieć menażerią i ogród. Z której pirwszej tyle ptactwa przedziwnych kolorów i zwirząt różnego gatunku, z Indii, z Afryki, Ameryki i państw przedtem dzikich, a teraz osiadłych, widząc, nie dałbym nigdy wiary, nie widząc. Która to ciekawość pociągnie mnie do powtórnego ich widzenia”; „Ruszyłem się szczęśliwie na Szenbrun [jw.] [...], gdzie powtórnie różne widząc źwirze, przyznałem życie tego nad nami zawiadowcy być barzo miłe, prawie z zajzdrością” (ibidem, s. 167).

${ }^{18}$ Wstępną rekonstrukcję gabinetu osobliwości Hieronima Floriana Radziwiłła przestawiłam w artykule Gabinet osobliwości Hieronima Floriana Radziwitta w Biatej, (tam też uwagi na temat rozmieszczenia eksponatów). W prezentowanym omówieniu skupiłam się jedynie na zbieranych przez niego obiektach przyrodniczych.

${ }_{19}$ Zob. m.in. K. Pomian, Zbieracze i osobliwości. Paryż, Wenecja, XVI-XVIII wiek, przeł. A. Pieńkoś, Warszawa 1996, m.in. s. 64-67; K. Strużyńska, Curiositas jako kategoria kultury doby baroku (XVI-XVII wiek), „Meluzyna. Dawna Literatura i Kultura” 2016, t. 3, nr 1 (4), s. 45; a także: A. R. Chodyński, Cztowiek w mikrokosmosie rzeczy rzadkich i dziwnych (XIII-XVIII w.), w: Curiositá - zjawiska osobliwe w sztuce, literaturze i obyczaju, red, A. S. Czyż, J. Nowiński, Warszawa 2013, s. 61. 
rządzące światem ${ }^{20}$. Oczywiście gabinety osobliwości, czy w ogóle różnego typu zbiory, miały także znaczenie jako wyraz prestiżu, bogactwa, władzy, przynależności do elit itp. Stanowiły również ważny element życia towarzyskiego i naukowego ${ }^{21}$.

Kryteria doboru eksponatów określał kolekcjoner ${ }^{22}$, zasadniczo jednak w czasach nowożytnych obiekty powinny być: niezwykłe, oryginalne, wyjątkowe, rzadkie, cudowne, wspaniałe, piękne i nowe (w znaczeniu: nieznane $)^{23}$. Chętnie stosowano też - bardzo pojemny semantycznie - termin: osobliwość ${ }^{4}$. Kolekcjonowanie było podniecane przez ciekawość, odnoszącą się zarówno do stanu umysłu zbieracza, jak i do cech zbieranych obiektów $^{25}$. Ta kategoria pojawiła się też w tytule rękopisu Hieronima Floriana Radziwiłła Rzeczy ciekawe, tak żywe, jako i różne, w którym wymienił najbardziej, według niego, godne uwagi obiekty swej kolekcji ${ }^{26}$. W diariuszu książę zamieszczał również informacje o nabytych kuriozach, niezwykłych

${ }^{20}$ A. Napierała, Wojciech Tylkowski wśród monstrów - barokowa scientia curiosa wobec estetyki epoki, „Amor Fati. Antropologiczne Czasopismo Filozoficzne” 2016, nr 1 (5), s. 221-223. Zob. też: M. Mencfel, Najdoskonalsza wiedza i petnia wiedzy. Kolekcjonerstwo i sztuka pamięci w epoce wczesnonowożytnej, w: Mnemonika i pamięć kulturowa epok daw$n y c h$, red. M. Prejs, A. Jakóbczyk-Gola, Warszawa 2013, s. 221-248.

${ }^{21}$ Zob. J. Czerzniewska, „Cabinet, kammera, stuiolo”. Konstrukcja wiedzy o niezwyktych przedmiotach i sztuce, w: Curiositá - zjawiska osobliwe w sztuce, literaturze i obyczaju, s. 29-36; K. Pomian, op. cit., s. 268.

22 O filozofii zbierania, wyborach kolekcjonera szerzej zob. M. Sommer, Zbieranie. Próba filozoficznego ujęcia, przeł. J. Merecki, Warszawa 2003 („Terminus”, t. 32).

${ }^{23}$ K. Strużyńska, op. cit., s. 38; F. Schock, Die Text-Kunstkammer. Populäre Wissenssammlungen des Barock am Beispiel der "Relationes Curiosae” von E. W. Happel, Köln-Weimar-Wien 2011 („Beihefte zum Archiv für Kulturgeschichte”, H. 68), s. 109.

${ }^{24}$ Pojęcie to analizuje np. M. Mencfel, Osobliwy, czyli jaki? Kategorie niezwyktości w kulturze naukowej, artystycznej, kolekcjonerskiej epoki nowożytnej, w: Curiositá-zjawiska osobliwe w sztuce, literaturze i obyczaju, s. 10-25.

${ }^{25} \mathrm{Na}$ temat tej kategorii w kontekście czasów nowożytnych napisano już wiele, zob. np. rozdział Kultura ciekawości w książce: K. Pomian, op. cit., s. 63-85, M. Mencfel, Skarbce natury i sztuki. Prywatne gabinety osobliwości, kolekcje sztuki i naturaliów na Ślasku w wiekach XVII i XVIII, Warszawa 2010, s. 36-40; F. Schock, op. cit., gł. s. 84-106.

${ }^{26}$ Rzeczy ciekawe, tak żywe, jako i różne (dalej Rzeczy ciekawe) stanowią część wspomnianych wyżej Rzeczy, którymi najgodniejszego moge zabawić gościa, s. 180-184; zob. K. Brzezina, op. cit., s. 13-16. 
rzeczach i zdarzeniach, o których słyszał lub przeczytał w kompendiach lub w prasie zagranicznej ${ }^{27}$. Zbiór księcia z jednej strony był zatem ukierunkowany na to, co ciekawe, zadziwiające, osobliwe, choć w niektórych przypadkach dopiero głębsza analiza kontekstu kulturowego pozwala na dostrzeżenie niezwykłości danego eksponatu. Z drugiej strony zdecydowaną większość w kolekcji stanowiły obiekty związane ze światem natury, które były z różnych względów wyjątkowe w świadomości księcia. Można więc przyjąć, że do pewnego stopnia zbiór ten był odpowiedzią na postulaty głoszone już w XVI wieku przez angielskiego filozofa Francisa Bacona, który m.in. pisał, że byłoby pożądane „przygotować zbiór czy częściową historię naturalną wszystkich dziwów i cudownych płodów natury, wszystkiego wreszcie, co w naturze jest nowe, rzadkie i niezwykłe"28. Biorąc pod uwagę kategorię osobliwości, trzeba uznać, że zbiór Radziwiłła należał do najpóźniejszych zbiorów w Europie, nawiązując do rozwiązań popularnych szczególnie w XVII wieku. Ukierunkowane na naturalia zbiory księcia oraz zainteresowanie magnata maszynami i przyrządami naukowymi należy z kolei uznać za rys już nowoczesnego podejścia ${ }^{29}$. Jako kontekst można tu przytoczyć wyniki badań Krzysztofa Pomiana, który na przykładzie Wenecji stwierdził, że zbieraczy naturalistów przed 1750 rokiem było tam bardzo niewielu, a dopiero po tej dacie liczba ich szybko wzrosła ${ }^{30}$. Zastanawiając się nad genezą kolekcji księcia Radziwiłła, w której punkt ciężkości stano-

${ }^{27}$ Zob. Diariusz zaczęty roku 1747 przeze mnie H[i]eronima księcia Radziwitta podczaszego wielkiego Wielkiego Księstwa Litewskiego pana i dziedzica dóbr catej Stucczyzny, w: Hieronima Floriana Radziwitta diariusze i pisma różne, s. 25-170 (dalej Diariusz). Wiedzę czerpano wówczas m.in. z różnych publikacji, np. jezuity Wojciecha Tylkowskiego (omówienie twórczości zob. J. Tazbir, Wojciech Tylkowski - polihistor ośmieszony, „Kwartalnik Historii Nauki i Techniki" 1978, t. 23, z. 1, s. 83-100; A. Napierała, op. cit.), encyklopedii Benedykta Chmielowskiego pt. Nowe Ateny, wydanej we Lwowie 1745-1746 (zob. szerzej B. Marcińczak, Historia naturalna w „Nowych Atenach” Benedykta Chmielowskiego, w: Cztowiek wobec natury - humanizm wobec nauk przyrodniczych, red. J. Sokolski, Warszawa 2010, s. 168-183). O znaczeniu książek i czasopism w czasach nowożytnych w zgłębianiu i porządkowaniu wiedzy, przydatnej też przy tworzeniu kolekcji, zob. F. Schock, op. cit.

${ }^{28}$ Cyt. za: M. Mencfel, Skarbce natury i sztuki, s. 39.

${ }^{29} \mathrm{O}$ zainteresowaniach technicznych Radziwiłła zob. K. Brzezina, op. cit., s. 9.

${ }^{30}$ K. Pomian, op. cit., s. 266-267. W innych regionach Włoch wcześniejszych czasowo zbiorów o charakterze przyrodniczym było więcej, zob. P. Findlen, Possessing Nature. 
wiły naturalia ze szczególnym uwzględnieniem zoologii, należy wziąć pod uwagę przede wszystkim zbiory cesarskie w Wiedniu i carskie w Petersbur$\mathrm{gu}^{31}$, a także najprawdopodobniej zbiory z terenu Holandii, gdzie książę przebywał w czasie swej młodości ${ }^{32}$.

Trzon kolekcji księcia Hieronima Floriana Radziwiłła stanowiła fauna. Wśród obiektów znalazły się spreparowane zwierzęta (np. zasuszony krokodyl, wypchane renifery, rajskie ptaki i papuga) oraz z różnych względów interesujące skóry, rogi, kości i zęby zwierząt, często pochodzących z pobliskich puszcz, ale też egzotycznych (np. skóry lwów, soboli, żubrów, węży), nabyte w drodze kupna, otrzymane jako podarunek lub odziedziczone ${ }^{33}$. Wartość niektórych z tych eksponatów podnosiła ich dawna metryka, jak to było w przypadku połączonych z sobą rogów jelenich, które zostały znalezione w puszczy za czasów Bogusława Radziwiłła ${ }^{34}$. Wypada tu podkreślić, że wiele obiektów w książęcym gabinecie było trofeami myśliwskimi, co znajduje też swoje odpowiedniki w innych zbiorach europejskich ${ }^{35}$. Dodajmy, że niekiedy książę zlecał wykonanie malarskiej dokumentacji wybranych zdobyczy łowieckich ${ }^{36}$.

W kolekcji nie zabrakło ponadto takich rarytasów, jak „róg rynocerosa” (nosorożca), „instrumenty miłości wielorybów”, „czerep wierzchniego żółwia indyjskiego”, „zęby słoniowe”, jaja strusie oraz zakonserwo-

Museums, Collecting, and Scientific Culture in Early Modern Italy, Berkeley-Los AngelesLondon 1996.

${ }^{31}$ Zob. K. Brzezina, op. cit., s. 11.

${ }^{32}$ Hieronim Florian Radziwiłł na pewno był w Lejdzie, zob. Diariusz, s. 154 (20 listopada 1750). O kolekcjach niderlandzkich zob. np. I. Arabas, Przyrodnicy, kolekcjonerzy i teoretycy muzealnictwa, „Kwartalnik Historii Nauki i Techniki” 2009, t. 54, nr 1, s. 118, 124.

${ }^{33}$ Rzeczy ciekawe, s. 181-182 oraz liczne diariuszowe wzmianki, dotyczące np. zakupów, m.in. Diariusz, s. 121 (28 listopada 1749), s. 122 (30 listopada 1749). Zob. też: K. Brzezina, op. cit., s. 8.

${ }^{34}$ Rzeczy ciekawe, s. 181.

${ }^{35}$ I. Kamińska, Elementy towieckie kunstkamer - Cabinet de la Licorne w Musée de la Chasse et de la Nature w Paryżu, w: Curiositá - zjawiska osobliwe w sztuce, literaturze i obyczaju, s. 414-423.

${ }^{36}$ Zob. Diariusz, s. 63 (13 stycznia 1748). 
wane w słojach egzotyczne węże, jaszczurki, ryby, pająki i „bazyliszek”37. W słojach książę przechowywał też płody upolowanych w okolicy zwierząt (np. lisów, wilków) ${ }^{38}$.

Świetności kolekcji księcia przydawała mumia egipska w sarkofagu, która w jego świadomości musiała być chyba wyjątkowo ważnym - o ile nie najważniejszym - obiektem. Może o tym świadczyć to, że wymienił ją na pierwszym miejscu Rzeczy ciekawych, tak żywych, jako i różnych ${ }^{39}$. Swą dawną metryką i wyjątkowością fascynowały też eksponaty uważane za fragmenty ciał wielkoludów ${ }^{40}$ oraz mitycznych stworzeń - smoka ${ }^{41}$ i jednorożca ${ }^{42}$, które powinny znaleźć się w tego typu kolekcji ${ }^{43}$.

Książęce zbiory były ponadto rozszerzone o „monstra” ${ }^{44}$. Hieronim Florian Radziwiłł odnotowuje w diariuszu nowe nabytki, podając zazwyczaj ich krótki opis, miejsce pochodzenia, niekiedy sposób pozyskania. W tym kontekście wypada nadmienić o wydanym przez niego w 1746 roku „edykcie o monstrach", w którym rozporządził, aby poddani w jego włościach przekazywali do Białej wszelkie kurioza ${ }^{45}$. Nie wszyscy poddani jednak stosowali się do tego rozporządzenia, co wiązało się m.in. z tym, że chłopi starali się nieraz ukryć narodziny „potworka”, który - jak wierzono - stakłady).

${ }^{37}$ Rzeczy ciekawe, s. 180-182. Por. K. Brzezina, op. cit., s. 8 (tam też dalsze przy-

${ }^{38} \mathrm{O}$ zbieraniu tego typu eksponatów wspomniano wielokrotnie w zapisach diariuszowych, zob. np. Diariusz, s. 34 (6 kwietnia 1747).

39 Rzeczy ciekawe, s. 180.

${ }^{40}$ Ibidem, s. 182 („żebro” i „członek ostatni małego u ręki palca”).

${ }^{41}$ Ibidem, s. 181 („górna kalwaria smoka”). Może tu chodzić o część kośćca wieloryba lub nosorożca dyluwialnego.

${ }^{42}$ Ibidem (,jednorożcowe rogi dwa”, czyli zapewne zęby narwala).

43 Zob. I. Kamińska, op. cit., s. 417-418.

44 W zbiorach Radziwiłła znajdowało się m.in. zakonserwowane w spirytusie „monstrum z Siebieża [...], mające nos elefanta, uszy wielkie jak ośle, jedne wielkie oko i łeb, ogon wielki psi, skąd i kopyta świnie, z której spłodzone” (Diariusz, s. 31; 4 marca 1747), „cielę dwugłowne” z Kojdanowa (ibidem, s. 33; 30 marca 1747), a także „dziecię dwugłowe, czteroręczne i tyloż nożne [...]" (ibidem, s. 63; 18 stycznia 1748).

45 Diariusz, s. 31 (4 marca 1747). O przechowywanych i hodowanych „monstrach” zob. też: K. Brzezina, op. cit., s. 9. 
nowił złą wróżbę $e^{46}$. Książę założył ponadto w swoich włościach specjalne zwierzyńce, gdzie żyły tego typu osobliwe stworzenia, jak konio-wielbłąd ${ }^{47}$, kuro-kaczory ${ }^{48}$ czy „koń armofrodit” ${ }^{49}$. Warto tu przypomnieć, że w tym czasie nie tylko Hieronim Florian interesował się zoologią i anomaliami natury, ale także choćby ówczesny cesarz, któremu pan na Białej przesyłał niektóre osobliwe okazy ze swej menażeriii ${ }^{50}$. W czasach nowożytnych „monstra”, a także inne osobliwości były pojmowane jako znak dany od Boga $^{51}$ i jako świadectwo kreacyjnych możliwości natury ${ }^{52}$. Mimo negatywnego postrzegania przez ludność wiejską lepiej wykształceni przedstawiciele społeczeństwa starali się walczyć z rozpowszechnionymi zabobonami. Do tych bardziej oświeconych należał też Hieronim Florian Radziwiłł.

W kontekście zaprezentowanego tu materiału wypada podkreślić, że w Europie miłośnicy przyrody częściej zbierali minerały i skamieniałości oraz rośliny, rzadziej natomiast powstawały kolekcje zoologiczne, na które składały się zazwyczaj części twarde ciał zwierząt (np. szkielety, zęby, pióra, muszle). Wiązało się to przede wszystkim z trudnościami technicznymi przy ich konserwacji ${ }^{53}$. Z tej perspektywy zoologiczna kolekcja księcia Radziwiłła wydaje się imponująca.

Książę Radziwiłł w swoich zbiorach posiadał także obiekty ze świata roślin. Te, które możemy złączyć z kolekcją (poza oranżeria), wyróżniały się pochodzeniem z odległych zakątków świata, jak „orzechy indyjskie”,

46 Do takiego zdarzenia doszło np. 27 kwietnia 1747 roku (Diariusz, s. 36): „Ten tedy monstrum przez sąd chłopów z rozkazu samej (gdyż samego ichmości nie było) jest zabite i wilkom do kniei na pokarm przez równą rekognicją ludzi jest zawiezione”. Zob. też: Rzeczy ciekawe, s. 183 („I lubo różne tu się zdarzają monstra, lud jeszcze od pogaństwa czasów zabobonny, ma sobie za największe nieszczęście, by miał dworowi donieść, zachowując tyż przy życiu, ale wraz ubiwszy, na błotach zakopuje jakoby rzecz srodze [...] szkodliwą"). O negatywnych konotacjach związanych z narodzeniem tego typu stworzenia zob. też np. A. R. Chodyński, Cztowiek w mikrokosmosie, s. 63.

${ }^{4}$ Diariusz, s. 141 (6 czerwca 1750).

48 Ibidem, s. 134 (21 marca 1750).

${ }^{49}$ Ibidem, s. 59 (14 grudnia 1747). Inne przykłady zob. też: Rzeczy ciekawe, s. 183.

${ }^{50}$ Rzeczy ciekawe, s. 183.

51 Zob. np. A. Napierała, op. cit., s. 231.

${ }_{52}$ M. Mencfel, Osobliwy, czyli jaki?, s. 19.

${ }^{53}$ K. Pomian, op. cit., s. 276. 
„szyszki zamorskie”, „migdały chińskie” i - przywieziony zapewne z krajów śródziemnomorskich - „korzeń mandragory, mający figurę św. Onufrego”, który był też widziany w kategoriach leczniczo-magicznych ${ }^{54}$. Fascynację egzotyką (a co za tym idzie też oryginalnością ze względu na miejsce pochodzenia $)^{55}$ dobrze widać w sporządzonym przez Radziwiłła opisie migdałów chińskich, które „skórę mają grubą i chropowatą, smak zaś onych lubo podobny do naszych ordynaryjnych, lecz przez swą tutaj niebywałość, skąd i osobliwość, zdadzą się być lepsze" 56 .

Świat przyrody nieożywionej w zbiorze Hieronima Floriana Radziwiłła reprezentowały kamienie i skamieniałości. Można hipotetycznie założyć, że sporą kolekcję minerałów odziedziczył on po przodkach, przede wszystkim zaś po matce Annie z Sanguszków Radziwiłłowej, która nie tylko lubiła kamienie, ale też organizowała poszukiwania geologiczne. Takie przedsięwzięcia, poza lepszym poznaniem zasobów ziemi, przyczyniały się też do gospodarczego rozwoju majątków, m.in. przynosząc odpowiedni surowiec do organizowanych przez księżnę szlifierni ${ }^{57}$. Książę w swoich pismach nie wspominał jednak o tego typu rodzinnych zbiorach. Wymienił on natomiast m.in. skamieliny, jak kliny piorunowe (czyli belemnity) czy kamień z odciskami ryb („sztuka kamienna, na której są dwie ryby wyryte”) ${ }^{58}$. Jeszcze większą uwagę przywiązywał do minerałów o specyficznym kształcie, kolorystyce czy rysunku (np. kamień z symbolem czerwonego krzyża) ${ }^{59}$. Jego kolekcja zawierała też sporo kamieni (lub tworów organicznych z wyglądu zbliżonych do kamieni) uznawanych za lecznicze lub magiczne,

${ }^{54}$ Rzeczy ciekawe, s. 180; K. Brzezina, op. cit., s. 8.

55 Zagadnienie to na przykładzie europejskich zbiorów wieloaspektowo omówił D. Collet, Die Welt in der Stube. Begegnungen mit Außereuropa in Kunstkammern der Frühen Neuzeit, Göttingen 2007 („Veröffentlichungen des Max-Planck-Instituts für Geschichte”, Bd. 232).

56 Diariusz, s. 63 (18 stycznia 1748).

57 W. Karkucińska, Anna z Sanguszków Radziwittowa (1676-1746). Dziatalność gospodarcza i mecenat, Warszawa 2000, s. 144-146, 149.

58 Rzeczy ciekawe, s. 183; K. Brzezina, op. cit., s. 8.

59 Książę znalazł minerał w kwietniu 1747 roku i jego wyglądowi przypisywał znaczenie symboliczne, zob. Diariusz, s. 35 (23 kwietnia 1747). Kamień ten jest zarówno dziełem przyrody, jak i znakiem męki Chrystusa. Zaciera się tu więc granica miedzy tym, co ziemskie, a tym, co nadprzyrodzone. Por. K. Pomian, op. cit., s. 100. 
zwane arkanami. Były to m.in. bezoary, „kamienie orle”, „kamienie żabie”, „kamienie krzyżowe”, czyli chiastolity (odmiana andaluzytu), „kamień od bolenia boku dla białych głów”, „kamień od bielma”60. O tym, jak cenił sobie tego typu obiekty, przekonuje cytat: „Orlich kamieni mam różnych kolorów, z których jeden w kolorze białym, pożyczony damie pewnej na czasach rozwiązania będącej, już mi się nie wrócił, czego nieodżałowanie spomnieć tu muszę jako rzecz dobrowolnie st [r]aconą, a waloru nieoszacowanego" ${ }^{61}$. Powyższe słowa można potraktować jako świadectwo wykorzystywania jeszcze w pierwszej połowie XVIII wieku tego typu magicznych środków.

Jak z tych przykładów wynika, księcia szczególnie interesowały kamienie, w których widział znaki dawane przez Opatrzność, oraz te, którym przypisywano funkcje lecznicze i magiczne. Takimi właściwościami - według ówczesnych przekonań - odznaczały się również m.in. różne części ciał zwierzęcych, np. rogi, kopyta, zęby. Za przykład może tu posłużyć kubek z rogu renifera, który Hieronim Florian kazał wykonać, gdyż - jak wyczytał - był on "antidotum do trucizny” 62 .

Gabinet osobliwości Hieronima Floriana Radziwiłła był niewątpliwie ważnym punktem na mapie tego typu kolekcji w Rzeczypospolitej. Był on ukierunkowany na obiekty przyrodnicze, które książę chętnie studiował. Wypada zaznaczyć, że w pierwszej połowie XVIII wieku stopniowo zmieniał się sposób formowania kolekcji. Już nie to, co osobliwe, a to co stałe, powtarzalne, zaczęło interesować zbieraczy. Pod tym względem zbiór księcia był już nieco anachroniczny, choć nadal zajmujący. Oddziaływania nowych prądów kolekcjonerskich, w których aspekt naukowy miał duże znaczenie, można by dopatrywać się w przyrodniczym (szczególnie zoologicznym) nacechowaniu zbioru Hieronima Floriana, a także w jednym z pomysłów tegoż magnata. W 1747 roku zanotował on mianowicie w diariuszu:

Umyśliłem sobie mieć gabinet taki, którego dotąd nicht czyli mieć nie chciał, czyli też nie mógł, to jest lat sośniny (o którą tu u nas najłatwiej)

${ }^{60}$ Rzeczy ciekawe, s. 180, 183; Diariusz, s. 122 (30 listopada 1749); K. Brzezina, op. cit., s. 8.

${ }^{61}$ Rzeczy ciekawe, s. 183.

${ }^{62}$ Ibidem, s. 181. 
od roku, ba, jeźli można, ćwierć roku do sta i z górą lat. Który to gabinet do widzenia onego, przyszedłszy do swej perfekcji, ściągnie słusznie ciekawych $[\ldots]^{63}$.

Ten nowy sposób myślenia ujawnia się przede wszystkim w chęci stworzenia specjalistycznego, systematycznego zbioru (który miał służyć nie tylko księciu, ale też innym zainteresowanym), a także w wyborze do realizacji tego zamiaru powszechnienie występującego w regionie drzewa.

\section{II}

Jak już wspomniano w części I artykułu, Hieronim Florian Radziwiłł na kartach diariusza jawi się nie tylko jako kolekcjoner, zgłębiający wiedzę o świecie natury ożywionej i nieożywionej, ale też jako osoba interesująca się wiedzą medyczną. To zainteresowanie widać już w omówionej kolekcji, gdzie ważne miejsce zajęły różnorodne środki, którym przypisywano własności lecznicze ${ }^{64}$. Przejawiało się ono również w poświęcaniu bacznej uwagi kwestiom własnego zdrowia oraz zdrowia członków swej rodziny (np. brata Michała Kazimierza zw. Rybeńko, ciotki Sapieżyny z domu Sanguszków, żony Magdaleny z domu Czapskiej), a ponadto przyjaciół domu (m.in. szambelana królewskiego Kazimierza Ottenhauza), wreszcie też niektórych dworzan.

W diariuszu książę starał się z reguły podawać nazwy chorób, z którymi się stykał, a niekiedy także stosowane w ich zwalczaniu środki. Na swoim dworze w latach 1747-1751 książę zatrudniał co najmniej czterech lekarzy, których w diariuszu wspominał z nazwiska: oberfelczera Johanna Davida Kuttnika, „lejbmedika” Johanna Fischera, felczera Gegiera i doktora me-

${ }^{63}$ Diariusz, s. 57 (29 listopada 1747). Nie wiadomo, czy idea ta została urzeczywistniona.

${ }^{64}$ Tradycja tych pasji książęcych musiała być silna, skoro Edward Kotłubaj w XIX wieku wspominał, że Hieronim Florian Radziwiłł „wierzył we wszystkie gusła i pełne księgi miał zapisane tak zwanemi arkanami, czyli środkami: przeciw chorobom, urokom, itp.” (zob. E. Kotłubaj, op. cit., s. 428). 
dycyny Giuseppe Gentilego ${ }^{65}$. Ze swoich medyków był dumny, o czym świadczą choćby słowa: „Zachorowała mi żonka dużo na gardło, nadzieję mam jednak w Bogu i w przednich u mnie doktorach, że w prędce do dawnego będzie przyprowadzona zdrowia” ${ }^{66}$. Epitet „przedni” w odniesieniu do jego dworskich medyków pojawia się często ${ }^{67}$. Wydaje się, że Radziwiłł rzeczywiście zatrudniał dobrych lekarzy, skoro był proszony o przysyłanie ich w trudniejszych przypadkach np. do ciotki, mieszkającej w Wisznicach, czy brata Michała Kazimierza, rezydującego głównie w Nieświeżu. Książęce zaufanie do medyków zostało jednak wystawione na próbę z powodu włoskiego doktora Gentiliego, który został przyjęty na dwór we wrześniu $1747 \mathrm{roku}^{68}$. W 1749 roku Hieronim Florian otrzymał anonimowy list, w którym oskarżono wspomnianego Włocha o chęć otrucia księcia. Zastrzegając się, że nie wierzy pomówieniom, książę na wszelki wypadek nakazał jednak aresztować medyka ${ }^{69}$. To właśnie od tego czasu Hieronim Florian stał się bardzo podejrzliwy i starał się za wszelką cenę chronić swe zdrowie, używając także „arkanów”, jak wspomniany już kubek z rogu renifera.

${ }^{65}$ Kuttnik: Diariusz, s. 44 (18 lipca 1747), s. 111 (4 sierpnia 1749); Fischer: Diariusz, s. 31 (3 marca 1747), s. 151 (30 października 1750); Gegier: Diariusz, s. 38 (10 i 11 maja 1747); Gentili: Diariusz, s. 49 (11 września 1747), s. 96 (5 marca 1749), s. 97 (6 marca 1749). O Kuttniku wspomniał Krzysztof Zuba, Chirurdzy, felczerzy i cyrulicy $w$ dobrach Radziwittów linii nieświeskiej w XVIII wieku, „Medycyna Nowożytna. Studia nad Kultura Medyczną” 1999, t. 6, z. 1, s. 80, 82, 87-88, 99. Autor ten podał też nazwiska innch lekarzy, zatrudnionych u Hieronima Floriana (z okresów, których nie obejmuje Diariusz), jak Johanna Ludwiga Merlata z Hamburga, przyjętego w 1738 roku na roczny kontrakt (s. 80, 99), i Johanna Friedricha Leydeckera, notowanego w służbach książęcych w latach 1756-1759 (s. 83, 87, 99), a ponadto nazwiska przedstawicieli różnych zawodów medycznych pracujących w Białej i Słucku (w tym za czasów rządów Hieronima Floriana). Pod koniec życia książę zatrudniał też nadwornego lekarza Dubickiego/Dubiskiego (zapewne chodzi o Gabriela Dubińskiego), zob. Pamiętnik Marcina Matuszewicza, s. 17, 82, 84. Kazimierz Bartoszewicz wspomniał też o lekarzu Fryderyku Bachströmie, zob. K. Bartoszewicz, op. cit., s. 110-112.

${ }^{66}$ Diariusz, s. 34 (9 kwietnia 1747).

${ }^{67}$ Np. ibidem, s. 34 (9 kwietnia 1747), s. 38 (10 maja 1747), s. 151 (30 października 1750).

${ }^{68}$ Ibidem, s. 49 (11 września 1747).

${ }^{69}$ Ibidem, s. 96 (5 marca 1749), s. 97 (6 marca 1749). 
Uspokoiła go dopiero przepowiednia, że wielkie szczęście lub nieszczęście spotka go w 47 roku życia (do którego to wieku zresztą nie dożył) ${ }^{70}$.

W tym miejscu wypada odnotować przynajmniej niektóre choroby i przypadłości, z którymi przyszło zmagać się Hieronimowi Florianowi Radziwiłłowi. Cierpiał on na migreny, kamicę moczową, okresowo leczył się na hemoroidy, zaparcia, diarę (czyli biegunkę) i przeziębienia. Nierzadko miewał też wysoką temperaturę połączoną z dreszczami, która mogła być spowodowana grypą, zapaleniem oskrzeli, ale też innymi chorobami. Z czasem prawdopodobnie doszły kłopoty z krążeniem ${ }^{71}$. Być może następstwem zaostrzenia kamicy było silne podrażnienie wątroby. W październiku 1748 roku książę zanotował w diariuszu:

Brałem rumbarbarum in substantia [wyciąg z rabarbaru], gdyż dużo się we mnie żółć była rozlała, której w niezabieżeniu pewnie bym był podległy żółtaczce. Do niej zaś już niezła być musiała aparencja, kiedy salvo respectu [z zachowaniem szacunku] czytelnika, uryna aloesowi się goryczą komparowała moja ${ }^{72}$.

Innym lekarstwem w walce z kamicą był - według słów leczonego czosnek oraz kamienie moczowe pite $\mathrm{w}$ winie $^{73}$. Ponadto zalecono księciu

${ }^{70}$ M. Brzezina, op. cit., s. 9. Zob. też: Diariusz, s. 148 (4 września 1750).

${ }^{71}$ Diariusz, passim. O tym, w jaki sposób leczono te dolegliwości, zob. publikacje Krzysztofa Zuby, który omawia większość z nich na przykładzie brata Hieronima Floriana - Michała Kazimierza „Rybeńki”: K. Zuba, O tym, jak „Rybeńkę” leczono. Kuracje i zabiegi medyczne Michata Kazimierza Radziwitta (1702-1762), „Medycyna Nowożytna. Studia nad Kulturą Medyczną" 2001, t. 8, z. 1, s. 89-109; idem, Michat Kazimierz Radziwitt (1702-1762) - portret psychofizyczny, „Medycyna Nowożytna” 2002, t. 9, z. 1-2, s. 53-84.

72 Diariusz, s. 85 (26 października 1748). Przy ocenie symptomów dolegliwości widać tu podejście empiryczne. Przypomnijmy przy tym, że rabarbar z jednej strony zawiera wiele przydatnych witamin i minerałów, z drugiej zaś kwas jabłkowy i szczawiowy, a ponadto usuwa wapń z organizmu.

73 Ibidem, s. 103 (18 kwietnia 1749). Radziwiłł w czasie jednej z podróży zatrzymał się w gościnie u księdza Michała Duńczewskiego w Zamościu: „[...] tak dla profitowania z przykładnych tego prałata przymiotów, jako tyż dla poratowania dużo naruszonego zdrowia przez kamień nagle czosnkiem skruszony, z którego ledwie mi życiem zapieczętować nie przyszło. I żebym był też ze mnie wychodzące nie pił kamienie w winie starte na proch, 
spacery, o czym świadczy cytat: „Jeździłem [...] na szpacjer według rozkazu doktorów, bym się często promenował przy mym defekcie kamienia [...]"74 . Sposoby te jednak nie odniosły pożądanego skutku, aż w końcu Hieronim Florian musiał w 1749 roku usunąć kamienie operacyjnie ${ }^{75}$. Wspomniany wyżej rabarbar był także lekarstwem przy zaparciach i wzdęciach ${ }^{76}$. W przypadku hemoroidów stosowano z reguły pijawki lub puszczanie krwi ${ }^{77}$. Księciu często puszczano krew, który to zabieg stanowił wówczas podstawową kurację przy bardzo różnych dolegliwościach ${ }^{78}$.

$\mathrm{Na}$ kartach diariusza pojawiają się niekiedy passusy dotyczące rozmów prowadzonych przez księcia z lekarzami, jednak nie z pozycji pacjenta, lecz co najmniej doradcy (np. „na konsylium [...] z doktorem trzymanym doszedłem [do wniosku]") ${ }^{79}$. O tym, że Hieronim Florian interesował się naukami medycznymi, a co więcej miał niejaką wiedzę na ten temat, świadczą też inne diariuszowe cytaty. Warto tu przytoczyć jeden z nich: „Zachorowałem był ciężko na krzyże, lecz z sobą mając przedniego doktora pana Fischera i sam też prawie mu równy, nie chwaląc się, będąc w medycynie, pro principali jednak łaską Stwórcy mego wraz prawie odebrałem folgę na zdrowiu" ${ }^{\circ 0}$. O ile w tego typu zdaniu można by dopatrywać się pewnej przesady, o tyle kolejne wywody dają podstawy sądzić, że powyższe stwierdzenie nie jest gołosłowne: „Jako tedy cokolwiek w medycynie peritus [doświadczony] jezdem, w lejdejskiej tam dawniej będąc akademii" ${ }^{\text {. }}$. Można zatem wyciągnąć wstępny wniosek, że w czasie swej wyprawy ka-

Bóg wie, coby ze mną było” (ibidem). O tej kuracji wspominał też J. W. Kobylański, Czary i zabobony myśliwskie księcia Hieronima Florjana Radziwitta, Warszawa 1935, s. 9.

${ }^{74}$ Diariusz, s. 84 (19 października 1748).

75 Operacji poddał się przed planowaną wyprawą do Gdańska, zob. K. Zuba, Michat Kazimierz Radziwitt (1702-1762), s. 67.

76 Wzmianki o właściwościach tej egzotycznej, jak na owe czasy, rośliny z Syberii, zob. np. Diariusz, s. 59 (19 grudnia 1747), s. 123 (21 grudnia 1749).

77 Ibidem, s. 105 (17 maja 1749), s. 111 (7-9 sierpnia 1749).

78 Ibidem, s. 105 (17 maja 1749), s. 141 (12 czerwca 1750).

79 Ibidem, s. 45 (3 sierpnia 1747). Nawiasem mówiąc, książę - jak się zdaje - doradzał też niekiedy lekarstwa przeciw dolegliwościom, zob. Gdybym Cię, moje serce, za męża nie miata, s. 184 (list z 8 września 1749).

${ }^{80}$ Diariusz, s. 151-152 (30 października 1750).

${ }^{81}$ Ibidem, s. 154 (20 listopada 1750). 
walerskiej Radziwiłł przez jakiś czas studiował medycynę na Uniwersytecie w Lejdzie. Z tej perspektywy nie dziwi zlecenie przez księcia sekcji zwłok jednego z muzyków, który nagle zmarł ${ }^{82}$, a także uzupełnianie przez niego wiedzy o „chorobach Wenery” we wsi Hrebennej, w której było skupisko medyków leczących tego typu dolegliwości. Nazwy medykamentów książę skrupulatnie odnotowat ${ }^{83}$.

$\mathrm{Z}$ jednej strony zatem widać u Radziwiłła podejście - można by powiedzieć - naukowe do zagadnień medycznych, z drugiej na kartach jego diariusza odbijają się też tradycyjne ludowe, magiczne i oparte na wierze religijnej, sposoby radzenia sobie $\mathrm{z}$ różnymi chorobami.

Przykładowo warto tu przypomnieć, że książę przez całe życie cierpiał na silną migrenę, jak twierdził, „zdobyczną z domu Sanguszków” Od 1747 roku jako remedium stosował „czapeczkę św. Bobolego”, którą przywiózł z Pińska, gdzie znajdowało się ciało bł. Andrzeja Boboli ${ }^{85}$. Wspomniane czapeczki koloru białego z wizerunkiem Andrzeja Boboli pocierano o ciało świętego i przekazywano potrzebującym. Czapeczka nie wyeliminowała wprawdzie migrenowych cierpień księcia, tym niemniej był on przekonany, że znacznie skróciła trwanie samego ataku ${ }^{86}$. Z prośbą o wyleczenie z różnych chorób zwracał się on też w modlitwach do św. Jozafata (którego ciało przechowywano w Białej) ${ }^{87}$, św. Wincentego Ferreriusza i św. Franciszka z Paoli ${ }^{88}$, a także do do Matki Boskiej, ku której czci, w podzięce za uzdrowienie z migreny, postanowił ufundować kościół w Horbowie (d. Horbowie Brzeskim ${ }^{89}$. Z diariuszowych wypowiedzi księcia wynika, że uleczenie z chorób było zawsze dla niego świadectwem łaski i opatrzności Boskiej.

${ }^{82}$ Ibidem, s. 112 (12 sierpnia 1749).

${ }^{83}$ Ibidem, s. 102 (15 kwietnia 1749).

${ }^{84}$ Ibidem, s. 25 (1 stycznia 1747).

85 W Pińsku był w maju 1747 roku, zob. ibidem, s. 39 (20-23 maja 1747).

86 Ibidem, s. 100 (5 kwietnia 1749). Ból trwał niemal cały dzień, dawniej zaś nawet dwie lub trzy doby.

${ }^{87}$ Ibidem, s. 113 (27 sierpnia 1749).

88 Ibidem, s. 71 (7 kwietnia 1748).

89 Ibidem, s. 156 (23 grudnia 1750). Warto nadmienić, że w Horbowie od XVI wieku znajdował się cudami słynący obraz Matki Boskiej Łaskawej. 
Magiczne myślenie, że podobne leczy podobne, przejawiało się natomiast m.in. w chęci posiadania krwi zajęczyc upolowanych w pierwszy dzień marca, który to środek miał leczyć czerwonkę.

Jeździłem w pole, nie tak dla mojej uciechy, jako chcąc się zdobyć w krew zajęczyc biegających w tym miesiącu, która jest jedynym od krwawych biegunek lekarstwem, gdy ją kto dosim [dawkując] na koniec noża da w ciepłym piwie wypić choremu, co nie na tysiącu rzecz jest już doświadczona. Obserwacja jednak jest ta, by pirwszego tego miesiąca byli bite, inaczej żadnego nie mają skutku ${ }^{90}$.

Interesującym przykładem leczenia sympatycznego jest sposób pozbycia się róży na twarzy, który Hieronim Florian Radziwiłł zaoferował swej ciotce Sapieżynie, wojewodzinie brzeskiej. Sekretny przepis polegał na zastosowaniu wysuszonego języka „marmurka sybirskiego”, przewiązanego zieloną wstążką ${ }^{91}$. Przypomnijmy, że magnat miał w swoich zbiorach cały arsenał środków przeciw różnym chorobom, o których wspomniano przy opisie jego zamiłowań kolekcjonerskich.

Jak widać, Hieronim Florian Radziwiłł interesował się przyrodą, w tym jej osobliwymi przejawami, o czym przekonują m.in. jego bogate, niestety już nieistniejące, zbiory. Zainteresowanie naturą łączyło się u niego z chęcią zgłębiania zagadnień medycznych, widzianych przez pryzmat wiedzy naukowej, wiary i magii, które to podejście było typowe w czasach barwnej barokowej kultury szlacheckiej w Rzeczypospolitej.

${ }^{90}$ Ibidem, s. 96 (1 marca 1749). W ten sam specyfik zaopatrywał się rok wcześniej (ibidem, s. 68). Zob. też: J. W. Kobylański, op. cit., s. 9.

91 Diariusz, s. 93 (27 stycznia 1749). 
